\title{
Az építészeti szerzői jogi szabályozás a jogérvényesítés tükrében
}

\author{
dr. Hartmann Zsófia - dr. Oláh Róbert
}

Az épitészeti szerzői jogi szabályozás módositásának eredménye, hogy a Il. világháború és a rendszerváltozás között állami forrásból készült épitészeti-müszaki dokumentációk szerzői vagyoni jogai egy helyre kerültek. A 2019. január 1-jén hatályba lépett törvénymódositás értelmében a volt állami tervezővállalatok többsége által készített tervek és a hozzá kapcsolódó jogok a Magyar Állam vagyonkezelésbe kerültek, ezáltal átépités vagy bővités esetén a felhasználási engedély jogszerü rendezése egyértelmübbé vált. A törvény által bevezetésre került a nemzeti tervvagyon fogalma, melynek körébe tartozó épitészeti alkotások és azok épitészeti-müszaki dokumentációinak kezelését a Magyar Állam tulajdonában álló Lechner Tudásközpont gyakorolja. A nemzeti tervvagyon megalakulása mellett létrejött az Épitészeti Szerzői Jogi Nyilvántartás, mint mindenki számára hozzáférhető adatbázis. A nyilvántartás célja, hogy a szerzői jogi oltalom alatt álló épitészeti alkotások szerzőjének és szerzői vagyoni jogosultjainak adatairól adjon tájékoztatást. A szabályozás nemcsak a tervezóvállalati tervek jogi helyzetét rendezte, hanem egyszerüsítette a beruházások elökészítésének jogosul kutatási folyamatát, illetve az épülettulajdonosok számára is megkönnyiti az átépités vagy felújitás menetét. A felhasználási engedély körülményeinek vizsgálatakor számos egyedi esettel lehet találkozni, melyeket a jogalkotó a törvénymódositás keretében megnyugtatóan rendezett.

Tárgyszavak: építészeti terv, műszaki dokumentum, szerzői jog, jogalkalmazás

\section{Bevezetés}

2015. év elején kezdődött meg az építészeti alkotásokhoz kapcsolódó szerzői jogi szabályozás felülvizsgálata a Miniszterelnökség és az Igazságügyi Minisztérium együttmúködésében. A mintegy öt éves munka során, amely a végül elfogadott törvényi, kormányrendeleti, miniszteri rendeleti és kormányhatározati szabályozásban öltött testet, a két tárca tüzetesen megvizsgálta a fennáló jogi szabályozást, és a lehető legnagyobb körültekintéssel alakította ki a végül hatályba lépett módosításokat. Mivel a felülvizsgálat megállapította, hogy a jogi szabályozás nem igényel alapvető változtatást, a módosítások a jogszabályok pontosítására, a fennálló rendszer konkretizálására irányultak.

Több mint két év eltelt azóta, hogy egy helyre kerültek a Il. világháború és a rendszerváltozás között állami forrásból elkészült építészeti-múszaki dokumentációk szerzői vagyoni jogai. A nemzeti tervva- gyon körébe tartozó dokumentumok felhasználásával kapcsolatban az elmúlt időszakban a Miniszterelnökség szakmai háttérintézményéhez, a Lechner Tudásközponthoz fordulhattak az érdeklődők.

Hazánk közhasználatú épületállománya - mint például kórházak, iskolák, művelődési házak, sportlétesítmények stb. - javarészt a kilencvenes éveket megelőző évtizedekben működő állami tervezővállalatok által tervezett építészeti alkotásból áll. Ezekkel a tervekkel kapcsolatban visszatérő problémát okozott sokáig a szerzői vagyoni jogok állami tulajdonlásának kérdése, ezzel elnyújtva, időnként ellehetetlenítve akár a kiemelt beruházások megindítását is.

\section{A volt állami tervezővállalatok által készített tervek szerzői jogi kérdései}

2019. január 1-jén lépett hatályba az egyes törvényeknek az építészeti alkotásokra, műszaki létesít- 
ményekre és azok terveire vonatkozó szerzői jogi szabályozással összefüggő, módosításáról szóló, 2018. évi CXXXIV. törvény (a továbbiakban: törvény), amely elfogadásával jelentősen egyszerűsödött az érintett építészeti alkotásokhoz kapcsolódó szerzői jogi jogérvényesítés.

A szerzői jogról szóló 1999. évi LXXVI. törvény (a továbbiakban: Szjt.) alapján, ha építészeti alkotás szerzői jogi értelemben vett felhasználása válik szükségessé például átépítés vagy bővítés esetén, az építészeti mű szerzői jogi jogosultjától (aki lehet az építész mint szerző, vagy munkaviszonyban készült tervek esetén a munkáltató) felhasználási engedélyt szükséges kérni. Felhasználási engedély felhasználási szerződéssel szerezhető, az engedélyért főszabályként felhasználási díj jár.

A probléma a múlt század második felében történt állami beruházások műszaki dokumentációjának szerzői jogai kapcsán az elmúlt években többek között az volt, hogy a még működő jogutódok szerzői jogi igénnyel léptek fel a jogelőd állami tervezővállalatok által, állami forrásból készített tervek felhasználása során, vagy más esetben a birtokukban lévő terveket értékesítették haszonszerzési céllal jogellenesen, ezzel időbeli és pénzbeli bizonytalanságot okozva az adott beruházás számára.

\section{Jogalkotói szándék}

A jogszabályi környezet módosításának egyik legfontosabb célkitűzése a volt állami tervezővállalatok keretében készített építészeti-műszaki dokumentációk jogi sorsának rendezése volt.

A hatályos szabályozás kiindulópontja az a jogalkotói meggyőződés volt, mely szerint azon jogutódlással megszűnt állami tervezővállalatok esetében, amelyek tervtárai, valamint az ezekhez kapcsolódó szerzői vagyoni jogok a privatizáció során nem kerültek be az átalakult társaság könyveibe és az átalakulási és végleges vagyonmérleg részét sem képezték, ott a tervek és az ezekhez kapcsolódó szerzői vagyoni jogok továbbra is az állam tulajdonában maradtak, külön ezt nevesítő jogszabály nélkül is.

Ennek megfelelően a törvény módosította az épített környezet alakításáról és védelméről szóló 1997. évi LXXVIII. törvényt (a továbbiakban: Étv.), melynek hatályos 55/B. §-a így rendelkezik: "a jogutódlással megszünt állami vagy tanácsi tulajdonú tervezővállalatokban létrehozott építészeti-müszaki dokumentációkhoz és az azok alapján megvalósított épületekhez füződő szerzői jog részét képező felhasználási jog vagy vagyoni jog a nemzeti vagyon részeként az államot illeti meg, kivéve, ha egyértelmüen igazolható, hogy a Magyar Állam a jogutódnak azt kifejezetten átadta."

A fenti jogszabályi rendelkezés egy megdönthető vélelmet állít fel, tehát lehetőség van annak hitelt érdemlő bizonyítására - például tervezési szerződéssel vagy egyéb okirattal -, hogy a jogutód az adott tervvagyonba tartozó immateriális eszközöket (jelen esetben szerzői vagyoni jogokat) a szervezetben fennálló vagyoni részesedéssel együtt privatizációs szerződésben a Magyar Államtól megszerezte. Ilyen esetben a jogutód társaság természetesen továbbra is szabadon rendelkezhet a szerzői vagyoni jogokkal, a felhasználás engedélyezéséért saját jogán díjigénnyel léphet fel. A törvény tehát nem kívánja megváltoztatni a szerzői vagyoni jogokat jogszerúen tulajdonlók jogi helyzetét, a tulajdoni viszonyokba nem avatkozik be. Bizonyítás hiányában a tervvagyonba tartozó tervdokumentációkra vonatkozó szerzői vagyoni jogok nem a privatizáló jogutódokat illetik meg. Ilyen módon a tervállomány a nemzeti vagyon részeként mindvégig a Magyar Államot illette meg.

A szabályozás mögött meghúzódó jogalkotói cél volt az is, hogy lehetővé váljon a nemzeti tervvagyon körébe tartozó tervdokumentációk kutatás céljából a beruházás előkészítése során történő rendelkezésre bocsátása. A mai középület-állomány az említett rendszerváltás előtti időszakban született, az ezekből megvalósult építmények átépítésének szükségessége gyakran felmerül. Az építészeti-múszaki dokumentációk jelentős hányada a gyakorlatban a kötelező átadási kötelezettség ellenére az egyes jogutód társaságok birtokában van, betekintésük erősen korlátozott, esetenként cégvezetői engedélyhez kötött.

A témához szervesen kapcsolódik a Lechner Tudásközpont által üzemeltetett Dokumentációs Központ és Nyilvántartás. A Lechner Tudásközpont Építésügyi Dokumentációs és Információs Köz- 
pontja az Építésügyi Dokumentációs és Információs Központról, valamint az Országos Építésügyi Nyilvántartásról szóló 313/2012. (XI. 8.) Korm. rendelet (a továbbiakban: Dok. Központ rendelet) 1. §j) pontja alapján kezeli a jogszabály által kötelezően, illetve önkéntesen átadott dokumentációkat, gyüjteményeket, dokumentumtárakat. A Központ jogelődjeit a korábbi jogszabályok szintén feljogosították arra, hogy gyűjtsék a megszűnő tervezővállalatoknak az érintettek által kötelezően benyújtott tervtárait. Annak ellenére azonban, hogy jelenleg is élő átadási kötelezettség vonatkozik e tervdokumentációk birtokosaira, a tervállomány jelentős részét még ma is magán tervtárak vagy magánszemélyek birtokolják és őrzik.

\section{A nemzeti tervvagyon fogalma}

A törvény a fentiekkel összhangban bevezette a nemzeti tervvagyon fogalmát. Nemzeti tervvagyon az Étv. 2. § 41. pontja értelmében: az építészeti alkotásoknak az állam és az önkormányzat tulajdonába tartozó építészeti-múszaki dokumentációi a honvédelmi, katonai, valamint nemzetbiztonsági célú és rendeltetésú építményeket érintő építészeti-múszaki dokumentációk kivételével -, valamint az azok vonatkozásában az államot és az önkormányzatot a mindenkori szerzői jogi szabályozás alapján megillető szerzői vagyoni, illetve felhasználási jogok összessége. Az Étv. hivatkozott rendelkezése értelmében ide kell érteni az állami tulajdonú szervezetek általi megrendelésre készült épületek azon építészeti-múszaki dokumentációit is, amelyen a megrendelő a szerzői vagyoni jogokat vagy a felhasználási jogokat megszerezte.

A jogutódlással megszúnt tervezővállalatok által készített tervek jogi helyzetét az előzőekben kifejtettük, lássuk, mi a helyzet a jogutód nélkül megszűnt tervezővállalatokkal. Ezek kapcsán két eset képzelhető el, attól függően, hogy az adott építészeti mű az Szjt. hatálybalépése, 1999. szeptember 1. után, vagy azt megelőzően készült. A megkülönböztetés oka az, hogy a régi szerzői jogi törvény a munkaviszonyban alkotott művek esetén a szerzői vagyoni jogok munkáltatóra történő teljes mértékű átszállásának lehetőségét nem ismerte, ennek megfelelően a munkáltató jogutód nélküli megszűnése esetén ez a jog visszaszállt a szerzői vagyoni jogok maradékával rendelkező tervezőre. Az új szerzői jogi törvény alapján - tekintettel arra, hogy a szerzői vagyoni jogok teljes egészében átszállnak a munkáltatóra - a munkáltató jogutód nélküli megszűnése esetén uratlan jogok keletkeznek. Az Étv. 55/A § (3) bekezdése alapján, "ha az állami vagy tanácsi, önkormányzati tulajdonú tervezővállalatok jogutód nélküli megszúnése miatt az ezek keretében létrehozott épitészeti-müszaki dokumentációhoz füződő szerzői felhasználási vagy vagyoni jogoknak nincs jogosultja, akkor e jogok a nemzeti vagyon részeként az államot illetik meg", ily módon e dokumentációk is a nemzeti tervvagyon körébe tartoznak.

\section{Az ajánlott kamarai díjszabás}

Abban az esetben, ha a jogutódlás során a jogutód szervezet a szerzői vagyoni jogokat megszerezte, illetve ha a jogutód nélkül megszűnt tervezővállalatok keretében készült tervek esetén a szerzői jog visszaszállt a tervezőre, a jogutód, illetve a tervező egy esetleges felhasználás során természetesen jogosult szerzői jogi igénnyel fellépni. Annak érdekében, hogy ezekben az esetekben is könnyebb legyen megegyezni a jogosulttal a felhasználás feltételeiről, a törvény felhatalmazza a Magyar Építész Kamarát és a Magyar Mérnöki Kamarát, hogy közös szabályzatban rögzítse a szerzői vagyoni jogok jogosultja által az építészeti alkotás és az építészeti-műszaki dokumentáció ismételt, az építészeti-múszaki dokumentáció alapján már megvalósított épülethez kötődő felhasználásért annak tulajdonosától kérhető, ajánlott díjakat. A kamarai díjak alkalmazása ugyan nem kötelező, de a joggyakorlat alakító hatásukon keresztül egyszerűsíthetik a felhasználási díjjal kapcsolatos viták lefolytatását.

Az Étv. 55/A. § (2) bekezdése úgy rendelkezik, hogy "a jogutód nélkül megszünt állami vagy tanácsi, önkormányzati tulajdonú tervező vállalatokban létrehozott épitészeti-müszaki dokumentációk esetében a vagyoni jogok jogosultja az épitészeti-müszaki dokumentáció felhasználásáért - eltérő megállapodás hiányában - a kamarai szabályzatban megállapított díjazást követelheti." Ha a jogosult a szabályzatban említett dijmértékét a felhasználás sajátos körülményeire tekintettel vitatja, a felek a szerzői jogi szakértő testület tagjaiból kijelölt egyeztető testülethez fordulhatnak. Ha a jogosult az egyeztető testület előtti eljárást megelőzően akként nyilatkozik, hogy a felhasználást engedélyezi, és csak 
az azért követelt felhasználási díj összegét vitatja, az egyeztető testület eljárásáért fizetendő díjat az állam viseli. Ha a jogosult a felhasználáshoz hozzájárult, és az egyeztető testület javaslatát a felek nem fogadják el, a jogosult bírósági úton érvényesítheti igényét, amely azonban a felhasználás megkezdését nem akadályozza, feltéve, hogy a felhasználó a szabályzat által ajánlott díjat letétbe helyezte.

\section{A nemzeti tervvagyon kezelése}

$\mathrm{Az}$ Étv. 4. $\S(3 \mathrm{c})$ bekezdése alapján "a nemzeti vagyonról szóló törvény szerint az állam tulajdonába tartozó, nemzeti tervvagyonnak minősülö, jogszabályban meghatározott épitészeti-müszaki dokumentációk folyamatos gyüjtése, megőrzése, a nemzeti tervvagyon jogszabályban meghatározottak szerinti vagyonkezelése állami feladat."

A Lechner Tudásközpont által üzemeltetett Dokumentációs Központ elsősorban a II. világháború utáni építészeti műszaki dokumentációk közgyűjteménye, kezeli a központi tervtár dokumentumait. Társaságunknál rendelkezésére áll a szükséges szakmai tudás a dokumentációk kezeléséhez, ezért volt kívánatos, hogy az építészeti műszaki dokumentációkhoz kapcsolódó vagyoni jogok tekintetében tulajdonosi joggyakorló is legyen.

Az Étv. 59/A. §-a értelmében a nemzeti tervvagyonnak a nemzeti vagyonról szóló törvény szerint az állam tulajdonába tartozó része vonatkozásában a tulajdonosi jogokat az állam 100\%-os tulajdonában álló Lechner Tudásközpont gyakorolja.

A Dok. Központ rendelet 1. § (1) bekezdés r) pontjában meghatározott, a nemzeti tervvagyont érintő dokumentumokat a rendelet 4. § (1) bekezdés alapján kötelező a Dokumentációs Központ részére elektronikusan vagy papír formátumban ingyenesen átadni, vagy megküldeni.

A tulajdonosi joggyakorlás keretében az Lechner Tudásközpont mérlegeli a felhasználási engedély kiadását, megállapítja a jogdíjakat és a felhasználás egyéb feltételeit, beszedi a jogdíjakat. A nemzeti tervvagyonba tartozó szerzői vagyoni jogok esetében a felhasználás engedélyezése körében az átdolgozásra is engedélyt adhat.

2019. január 1-jétől tehát, amennyiben a nemzeti tervvagyon körébe tartozó épület vonatkozásában beruházás, bővítés, átépítés válik szükségessé, az áttervezésért (átdolgozásért) a szerzői vagyoni jogosulttól, vagyis a Lechner Tudásközponttól szükséges engedélyt kérni, a felhasználási engedély pedig főszabály szerint felhasználási díjköteles.

Amennyiben nem történik átalakítás, hanem a nemzeti tervvagyon körébe tartozó épület helyreállítása az eredeti tervek szerint valósul meg, úgy a terv használata ingyenes, csak annak digitalizálásáért, másolat készítéséért kell díjat fizetni a Lechner Tudásközpont részére. Helyreállítás alatt az újjáépítés, valamint az a felújítás értendő, amely azt célozza, hogy az épület rendeltetésszerű, biztonságos használatra alkalmassá váljon, az eredeti építészeti kialakítás megtartásával.

A nemzeti tervvagyon körébe tartozó épület felhasználásra vonatkozó igény esetén tehát a tulajdonosi joggyakorló Lechner Tudásközpont az erre vonatkozó megkeresés esetén - az Szjt. rendelkezéseinek megfelelően - az Üzemeltetési és Adatkezelési Szabályzatában meghatározottak szerint felhasználási engedélyt adhat. A Lechner Tudásközpont honlapján is megtalálható díjszabás szintén az Üzemeltetési és Adatkezelési Szabályzatban került meghatározásra.

\section{Az épülettulajdonosoknak kedvezö, új rendelkezések}

A törvény tartalmaz módosításokat annak érdekében is, hogy az épülettulajdonosok könnyebben tudják a tulajdonukban álló épületet felújítani vagy átépíteni.

Ebben a körben problémát jelentett korábban az az eset, amikor a felhasználás engedélyezése kizárólagosan a szerzőt illette meg, de a szerző kiléte ismeretlen volt, vagy az ismert szerző ismeretlen helyen tartózkodott. Ilyen esetben árva műről beszélünk, amely felhasználását a Szellemi Tulajdon Nemzeti Hivatala (a továbbiakban: SZTNH) engedélyezi, az engedély azonban korábban nem terjedt ki a mú átdolgozására. Tekintettel arra, hogy a már meglévő építészeti alkotások vonatkozásában a jellemző felhasználási mód az átépítés, áttervezés (átdolgozás), az árva művek felhasználása sokszor gyakorlati nehézségekbe ütközött. A törvény az árva mű felhasználásának engedélyezését az építészeti alkotások vonatkozásában - az európai uniós szabályokkal összhangban - kiterjeszti az átdolgozás vagyoni jogának engedélyezésére. Az átdolgozásra is kiterjedő engedély kizá- 
rólag az épület tulajdonosának adható. A törvény lehetővé teszi azt is, hogy az engedély 5 évre szóló időtartamát az SZTNH kérelemre további 5 évvel meghosszabbítsa.

$A z$ épülettulajdonosok helyzetét könnyíti az a rendelkezés is, mely szerint az épület helyreállítása céljából a terv szabadon felhasználható. Ez a szabály a tulajdonosoknak a tulajdonukban álló épület karbantartásához fúződő jogos érdekeit védi, a tervező jogos érdekeit a lehető legkevésbé sértő módon. A szabad felhasználási eset lehetővé teszi az épület rekonstrukciója érdekében épület, rajz vagy épületterv formájában megjelenő művészeti alkotás engedély- és dífiizetés nélküli többszörözését és a nyilvánosság számára történő hozzáférhetővé tételét. A bevezetett szabad felhasználási eset célhoz kötött, vagyis csak az épület rekonstrukciója, eredeti állapotba történő helyreállítása érdekében kerülhet rá sor. Meghatározásra került a törvényben a helyreállítás fogalma is, az Szjt. 68. § (4) bekezdése értelmében "helyreállitás az újjáépités, valamint az épitészeti alkotás rendeltetésszerü és biztonságos használatra alkalmassá tétele érdekében végzett felújitási tevékenység az épitmény, épitményrész eredeti épitészeti kialakitásának megtartása mellett".

\section{Az építészeti szerzői jogi nyilvántartás}

A törvény alapján a Lechner Tudásközpont feladata volt az építészeti szerzői jogi nyilvántartás létrehozása és működtetése is. Jelenleg az adatbázis bárki által kereshető ügyfélkapus belépést követően.

Az építészeti alkotások szerzői jogi nyilvántartásával megvalósult annak lehetősége, hogy az érdekeltek erre irányuló külön kutatás nélkül tájékozódni tudjanak az adott szerzői jogi oltalom alá eső építészeti alkotás szerzőjének és szerzői vagyoni jogosultjainak adatairól. Ennek köszönhetően a felhasználók a szerzői jogi jogosultak jogainak tiszteletben tartásával, jogszerű felhasználási engedély birtokában tudnak eljárni a művek felhasználása során, ezáltal számos jogvita megelőzhető.

A távlati cél, hogy a nyilvántartásban elérhetőek legyenek az állami tulajdonú, a nemzeti tervvagyonba tartozó épületekre vonatkozó adatok is, vagyis egyértelműen fellelhető lesz, hogy ezen épületek és tervek vonatkozásában a szerzői vagyoni jogok jogosultja a Magyar Állam, a tulajdonosi joggyakorló pedig a Lechner Tudásközpont.

\section{Beérkezett: 2021. október 25.}

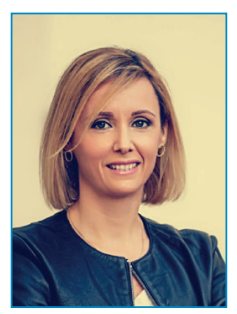

\section{dr. Hartmann Zsófia}

jogtanácsos

E-mail: hartmann.zsofia@gmail.com

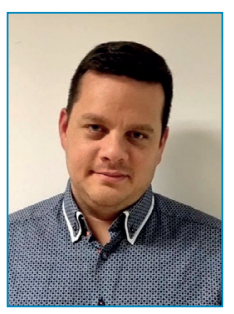

\section{dr. Oláh Róbert}

jogtanácsos

Lechner Tudásközpont

E-mail: robert.olah@lechnerkozpont.hu 